Highly enantioselective trifluoropyruvate-ene

Leave this area blank for abstract info. reactions with steroidal side chains catalyzed by dicationic palladium Lewis acid complex for latestage fluoromethyl-functionalization: Remarkable high agonist and antagonist activities of the ene products even in low VDR binding affinity

Kumiko Fujita, Junpei Aida, Koichi Mikami*
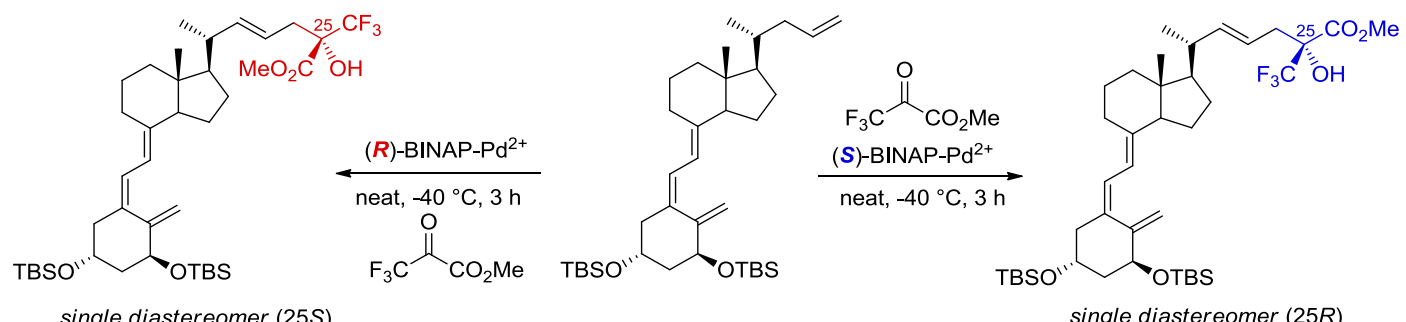

sinale diastereomer $(25 S)$

single diastereomer $(25 R)$ 


\title{
Chiral Pd-catalyzed trifluoropyruvate-ene reactions with steroidal side chains for late-stage fluoromethyl-functionalization: Remarkably high agonist activities of ene products even in low VDR binding affinity ${ }^{\dagger, \S}$
}

\author{
${ }^{\dagger}$ Dedicated to Professor Jiro Tsuji in the honor of his Tetrahedron Prize
}

\author{
Kumiko Fujita, Junpei Aida, Koichi Mikami* \\ Department of Applied Chemistry, Graduate School of Science and Engineering, Tokyo Institute of Technology, O-okayama, Meguro-ku, Tokyo $152-8552$ (Japan)
}

\section{ARTICLE INFO}

\section{ABSTRACT}

\section{Article history:}

Received

Received in revised form

Accepted

Available online

\section{Keywords:}

ene reaction

palladium catalyst

trifluoromethyl

vitamin $\mathrm{D}_{3}$

agonist

\begin{abstract}
The highly enantioselective trifluoropyruvate-ene reactions of chiral steroid side chain olefins were achieved by dicationic palladium complexes as chiral Lewis acid catalysts to give steroidal ene-products in high diastereoselectivity. The ene products exhibited remarkably high agonist activities for human osteocalcin even in low vitamin D receptor binding affinity for human vitamin D hormone receptor.
\end{abstract}

2009 Elsevier Ltd. All rights reserved.

\section{Introduction}

In modern organic synthesis, palladium complexes have been widely employed as effective catalysts for carbon-carbon bond formation ${ }^{1}$ as highlighted in the Nobel prize in Chemistry 2010 on the "Palladium-Catalyzed Cross-Coupling Reactions" primarily based on their stable oxidation states $(\operatorname{Pd}(0)$ and $\mathrm{Pd}(\mathrm{II}))$ via 1) $\mathrm{Pd}(0)$ to/from $\mathrm{Pd}(\mathrm{II})$ redox catalytic cycles, 2) $\mathrm{Pd}(\mathrm{II})$ to $\mathrm{Pd}(\mathrm{II})$ catalytic cycles, and 3) $\mathrm{Pd}(\mathrm{II})$ to/from comparatively unstable Pd(IV) catalytic cycles. The Pd(II) to Pd(II) catalytic cycles are further classified into 2-1) Pd(II) Lewis acid catalysis particularly with coordinatively unsaturated sixteen-electron dicationic $\mathrm{Pd}(\mathrm{II})$ complexes in preference to the neutral $\mathrm{Pd}(\mathrm{II})$ complexes and 2-2) $\mathrm{Pd}(\mathrm{II})$ to $\mathrm{Pd}(\mathrm{II})$ catalysis involving simultaneous oxidation process of the $\operatorname{Pd}(0)$ intermediary state; We have already reported the first example of asymmetric catalytic intermolecular $\mathrm{C}-\mathrm{H}$ bond activation/C-C bond formation, namely Fujiwara-Moritani reaction ${ }^{2}$ via simultaneous oxidation with perbenzoic $\mathrm{acid}^{3}$ (Scheme 1) and the Claisen rearrangement ${ }^{5}$ (Scheme 2$)^{6}$ catalyzed by the chiral neutral Pd(II) catalysts, Pd(II)-OxNTf and Pd(II)-DABNTf catalysts, respectively; In contrast to the generally observed $E \rightarrow$ syn diastereoselectivity through the widely accepted six-membered chair-like Claisen transition state, an intriguing $E \rightarrow$ anti diastereoselectivity was found via the rarely precedented boatlike transition state (A) along with high enantioselectivity (up to
$83 \%$ ee) by the carbophilic Lewis acid Pd(II)-DABNTf catalyst (Scheme 2). As chiral cationic Pd(II) catalysts, we have also developed dicationic biphenylphosphine (BIPHEP)- and BINAP$\mathrm{Pd}(\mathrm{II})$ complexes with strongly anionic ligands such as hexafluoroantimonate $\left(\mathrm{SbF}_{6}{ }^{-}\right)$as effective chiral Lewis acid catalysts for the carbonyl-ene ${ }^{7}$ and Friedel-Crafts ${ }^{8}$ reactions with 1,2-dicarbonyl chelate substrates such as glyoxylate and trifluoropyruvate.

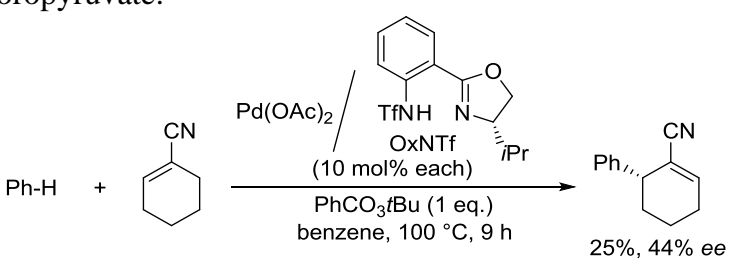

Scheme 1.

* Corresponding author. Tel.: (+81)3-5734-2142; fax: (+81)3-5734-2776; e-mail: mikami.k.ab@m.titech.ac.jp 


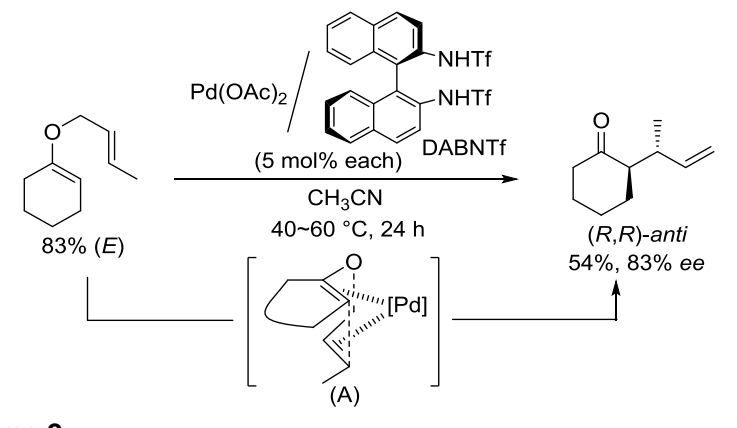

Scheme 2

Why are these $\mathrm{Pd}(\mathrm{II})$ complexes so effective as Lewis acidic catalysts? Mellor and Maley orders of stability of the first and second transition series of divalent metals with bidentate chelate substrates such as salicylaldehyde, glycine, 8-hydroxyquinoline, and ethylenediamine are $^{9}$ (Values in parenthese () are AllredRochow electronegativity scale. Values in parenthese [] are tetrahedral or square planar Pauling covalent radii.): $\mathrm{Pd}$ (1.35) [1.32] > Cu (1.75) [1.32] > Ni (1.75) [1.39] > Co (1.70) [1.32] > $\mathrm{Zn}(1.66)[1.31]>\mathrm{Fe}(1.64)>\mathrm{Mn}(1.60)>\mathrm{Mg}(1.23)$ [1.40]. $\operatorname{Pd}(\mathrm{II})$ complexes are therefore the most stable and more Lewis acidic complexes than $\mathrm{Cu}$ (II) complexes, with bidentate chelate substrates positioning neighbouring functionalites. Although Lewis acidities of metal complexes are dependent on ligands associated therewith.

Organofluorine compounds have attracted current attention in the fields of pharmaceuticals, agrochemicals, and organic materials by virtue of their unique chemical, biological, and physical properties. ${ }^{10}$ In drug design, trifluoromethyl-functionalities are logically employed, because trifluoromethyl groups can render higher stability of $\mathrm{C}-\mathrm{F}$ bond and neighboring chemical bonds against oxidative metabolism, and can simultaneously increase lipophilicity and polarity in drug candidates. ${ }^{11}$ Therefore, a variety of synthetic methods to introduce trifluoromethylfunctionalities into organic molecules have been reported to afford the trifluoromethyl-substituted analogues, even in optically active forms. Particularly, $\alpha$-trifluoromethylsubstituted tertiary alcohols synthesized via the catalytic asymmetric carbon-carbon bond formation have attracted current interest due to the unique biological activities of drug candidates such as trifluoromethylated glucocorticoid receptor agonists. ${ }^{12}$

Fluorinated steroids, ${ }^{13}$ vitamin D analogues, ${ }^{14}$ in particular have attracted much attention in their synthesis, biochemistry and biological activities. 25-Bis(trifluoromethyl) vitamin D analogue is now in market as "Hornel", falecalcitriol, namely $26,26,26,27,27,27$-hexafluoro analogue of the active form of 1,25-dihydroxy vitamin $\mathrm{D}$ against further oxidative metabolism at 26 and/or 27, and with increased lipophilicity. ${ }^{15}$ Therefore, synthetic methods to introduce single trifluoromethyl functionality into biologically active metabolites of 1,25dihydroxy vitamin $\mathrm{D}$ in asymmetric manner have been required in order to further examine their biological activities. Trifluoromethyl analogues of active metabolites as tertiary 25alcohol derivatives, such as 26,23S-lactone and its' intermediates ${ }^{16}$ bearing the quaternary carbon centers ${ }^{17}$ can be synthesized via the catalytic asymmetric carbonyl-ene reactions with trifluoropyruvate ("trifluoropyruvate-ene reactions"). ${ }^{7 \mathrm{~d}, \mathrm{e}}$

Herein, we report the highly enantioselective trifluoropyruvateene reactions as one of the most atom economical ${ }^{18}$ and catalytic asymmetric carbon-carbon bond formations, catalyzed by dicationic palladium complexes as the most effective chiral Lewis acid catalysts to provide trifluoromethyl analogues of 26,23S-lactone and synthetic intermediates.

\section{Results and discussion}

Initially, we evaluated the transition-metal complexes, which can be utilized efficiently as a Lewis acid catalyst, in trifluropyruvate-ene reaction with isobutene (Table 1). ${ }^{19, \$ b}$ Encouraged by the excellent enantioselectivities, we investigated the dicationic Pd complexes 1a-d ( $5 \mathrm{~mol} \%$ ) prepared in situ from the corresponding dichloride complex and two equivalents of $\mathrm{AgSbF}_{6}$ (Table 1). As chiral ligands in the dicationic palladium catalysts, $(S)$-BINAP, $(S)$-MeO-BIPHEP, $(S)$-tol-BINAP, and $(S)$-SEGPHOS exhibited the excellent yields and enantioselectivities (entries 1-4). These reactions proceeded smoothly even under solvent-free conditions to provide the corresponding trifluropyruvate-ene products 3 within 10 minutes (entries 1-4). When the cationic box-copper catalysts, one of the most efficient Lewis acids, ${ }^{20}$ were employed, the solvent-free conditions were not appropriate regardless of the counter anions widely screened (entries 5-6). Although the copper catalysis (0.01 mol\%) was facilitated in $\mathrm{Et}_{2} \mathrm{O}$ and led to the excellent results $(99 \%$ yield, $99 \%$ ee $)$, the catalytic activity was extremely lower even in $0.1 \mathrm{~mol} \%$ catalyst loading (14-24 h) than that of the palladium catalysts (entries 8 vs. 1-4: $10 \mathrm{~min}, 0.01 \mathrm{~mol} \%$ ). Unfortunately, the iron catalyst decreased both in the catalytic activity and enantioselctivity (entry 9). As a result, we concluded that the $\mathrm{Pd}$ catalyst $\mathbf{1 a}$ in entry 1 was the best catalyst in trifluoropyruvate-ene reaction, due to higher performance of catalytic activity and lower-cost of the chiral ligands. ${ }^{19}$

\section{Table 1}

\begin{tabular}{|c|c|c|c|c|c|}
\hline entry & cat $^{*}$ & $\mathrm{x}$ & conditions & $\operatorname{conv}(\%)^{\mathrm{b}}$ & $e e(\%)^{\mathrm{c}}$ \\
\hline 1 & $1 a$ & 0.01 & neat, $-20^{\circ} \mathrm{C}, 10 \mathrm{~min}$ & 94 & 96 \\
\hline 2 & 1b & 0.01 & neat, $-20^{\circ} \mathrm{C}, 10 \mathrm{~min}$ & 98 & 98 \\
\hline 3 & 1c & 0.01 & neat, $-20^{\circ} \mathrm{C}, 10 \mathrm{~min}$ & 96 & 91 \\
\hline 4 & 1d & 0.01 & neat, $-20^{\circ} \mathrm{C}, 10 \mathrm{~min}$ & 90 & 96 \\
\hline 5 & $1 e$ & 0.01 & neat, $-20^{\circ} \mathrm{C}, 24 \mathrm{~h}$ & 74 & 14 \\
\hline 6 & $1 f$ & 0.01 & neat, $-20^{\circ} \mathrm{C}, 24 \mathrm{~h}$ & 69 & 41 \\
\hline 7 & $1 f$ & 0.01 & $\mathrm{Et}_{2} \mathrm{O},-20^{\circ} \mathrm{C}, 14 \mathrm{~h}$ & 64 & 72 \\
\hline 8 & $1 f$ & 0.1 & $\mathrm{Et}_{2} \mathrm{O},-20^{\circ} \mathrm{C}, 14 \mathrm{~h}$ & 99 & 99 \\
\hline 9 & $1 \mathrm{~g}$ & 10 & $\mathrm{CH}_{2} \mathrm{Cl}_{2},-20^{\circ} \mathrm{C}, 20 \mathrm{~h}$ & 65 & 12 \\
\hline
\end{tabular}

alsolated yield. ${ }^{\mathrm{C}}$ Enantiopurity was determined by chiral HPLC anlysis.

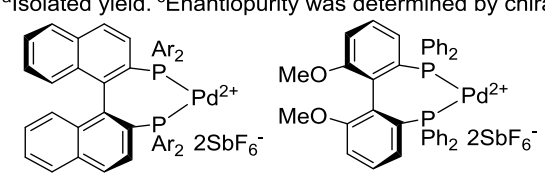

(S)-BINAP-Pd: 1a $(\mathrm{Ar}=\mathrm{Ph})$

(S)-tol-BINAP-Pd: 1b $\left(\mathrm{Ar}=4-\mathrm{MeC}_{6} \mathrm{H}_{4}\right)$

(S)-MeO-BIPHEP-Pd: 1c

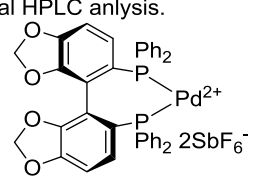

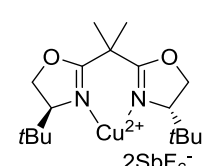

$1 \mathrm{e}$
(S)-SEGPHOS-Pd: 1d

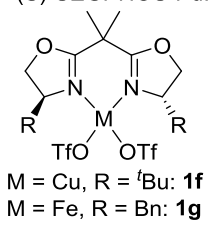

We applied the highly enantioselective trifluoropyruvate-ene reactions catalyzed by the dicationic Pd complexes 1a to steroidal olefins for late-stage trifluoromethyl-functionalization (Scheme 3). The steroidal olefin 4 could be employed for the ene reactions in the catalysis of the Pd complexes, $(R)-\mathbf{1 a}$ and $(S)-\mathbf{1 a}$ to afford $(25 S)-\mathbf{5}$ and $(25 R)-\mathbf{5}$ as single diastereomers in $81 \%$ and $76 \%$ yields, respectively, although the relatively high catalyst loading (10 mol\%) was employed for smooth reactions; The absolute stereochemistry for vitamin $\mathrm{D}$ analogs follows the general rule: $(R)$ - and $(S)$-1a afford $(S)$ - and $(R)$-ene products. 


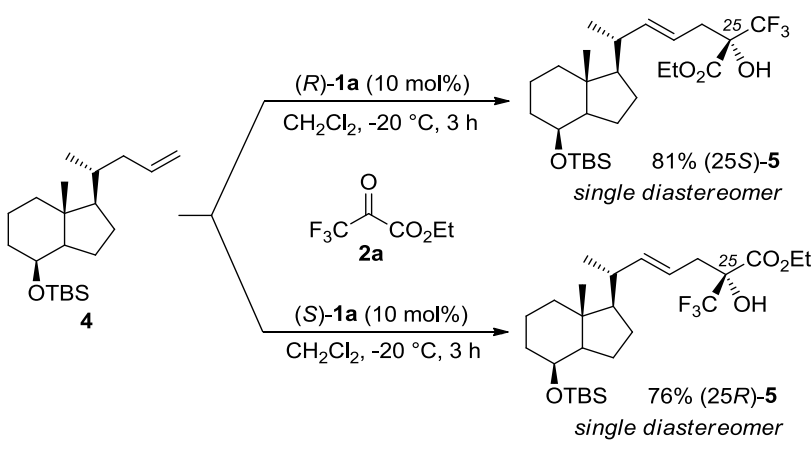

Scheme 3.

Next, we investigated as to whether the direct lactonization of steroidal ene products proceeds or not under the dicationic palladium catalysis (Scheme 4). In view of the sequencial ene and lactonization reactions by the dicationic Pd catalysts, the direct lactonization of the ene-product 3 obtained from isobutene was first examined to provide the corresponding lactone 6 in $45 \%$ isolated yield (Eq. 1). Furthermore, examination of tandem trifluropyruvate-ene and lactonization sequence starting from isobutene gave the lactone product 6 in $38 \%$ isolated yield (Eq. $2)$. Unfortunately however, the steroid ene product (25S)-5 was not able to transform to lactone $\mathbf{7}$ by $(S)$-1a under various reaction conditions (Eq. 3).

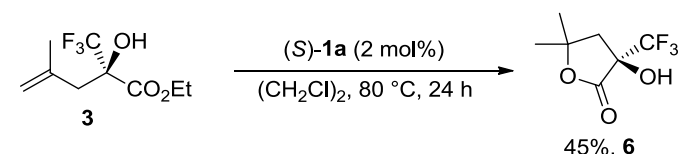
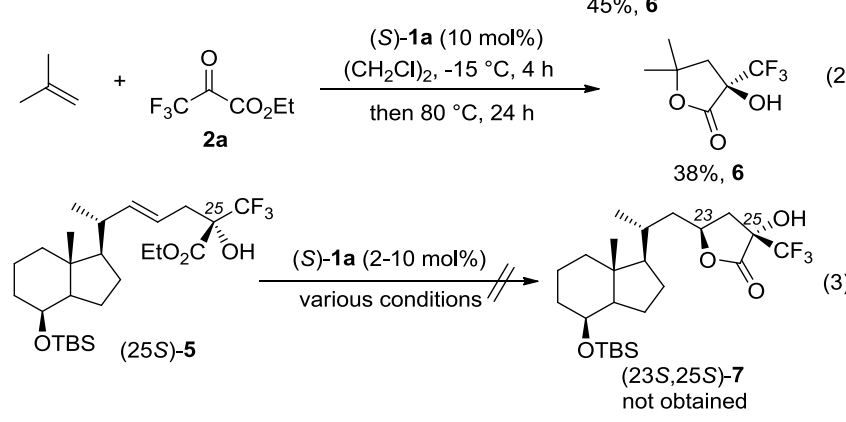

\section{Scheme 4.}

(1)<smiles>C[C@H](/C=C\CC(O)(O)C(F)(F)F)[C@H]1CCC2C(O)CCCC21C</smiles>

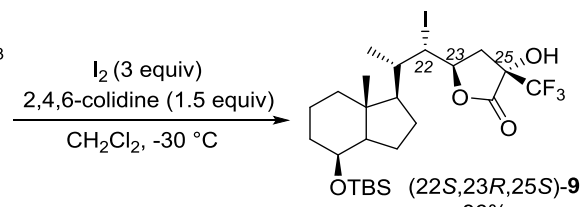
$86 \%$
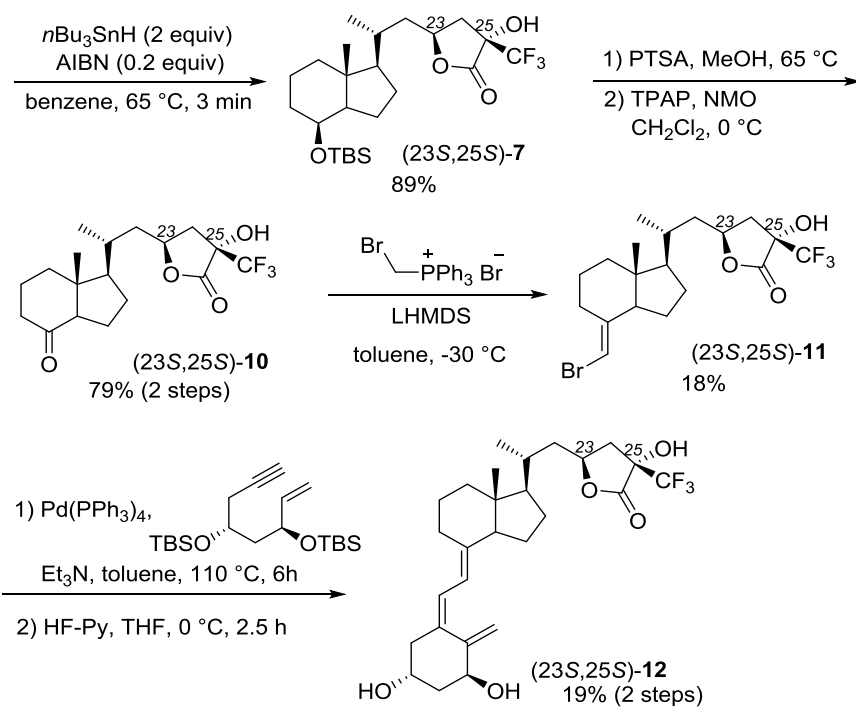

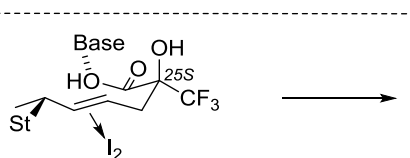

(B)

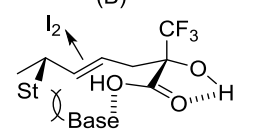

(C)

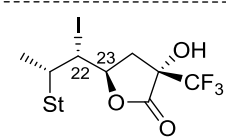

$(22 S, 23 R, 25 S)$<smiles>CC(Cl)[C@H](I)[C@@H]1C[C@@](O)(C(F)(F)F)C(=O)O1</smiles>

$(22 R, 23 S, 25 S)$

\section{Scheme 5.}

Therefore, iodolactone $(22 S, 23 R, 25 S)-9$ was synthesized via the hydrolysis of ester $(25 S)-\mathbf{5}$ followed by the iodolactonization with $\mathrm{I}_{2}$ and 2,4,6-colidine. ${ }^{21}$ The trifluoromethyl analogue 9 of natural-type lactone was obtained in $86 \%$ yield as virtually single diastereomeric form $(>99 \%)$ via the favorable six-membered transition state (B) with the sterically demanding trifluoromethyl group in equatorial orientation, by decreasing the amount of colidine up to 1.5 equivalent in dichloromethane rather than acetonitrile at $-30{ }^{\circ} \mathrm{C}$ (Scheme 5). The reduction of (22S,23R,25S)-9 using $n \mathrm{Bu}_{3} \mathrm{SnH}$ and AIBN led to the lactone (23S,25S)-7 in $89 \%$ yield. The desilylation and oxidation of the silyl ether $\mathbf{7}$ gave ketone $(23 S, 25 S)$-10 in $92 \%$ yield, then bromoolefin $(23 S, 25 S)-\mathbf{1 1}$ was obtained by the Wittig olefination reaction with lithium hexamethyldisilazide. Finally, the steroidal C,D-ring with bromo-olefin 11 underwent the Pd-catalyzed Trost A-ring attachment ${ }^{22}$ with the chiral A-ring portion of enyne to afford the trifluoromethyl analogue 12 of natural-type calcitriol lactone in $56 \%$ isolated yield.

Significantly, steroid olefin $\mathbf{1 3}$ even with labile B-ring triene portion could be employed for our trifluoropyruvate-ene reaction in the presence of $(R)$-1a under solvent-free conditions, providing the desired product $(25 S)-\mathbf{1 4}$ in $43 \%$ isolated yield as a single diastereomer (Scheme 6, Eq. 1). The result clearly indicates that our Pd-catalyzed trifluoropyruvate-ene reaction is efficiently applicable for late-stage fluoromethyl-functionalization. As expected, $(S)$-1a under the same reaction conditions gave the opposite single diastereomer (25R)-14 (Eq. 2). 


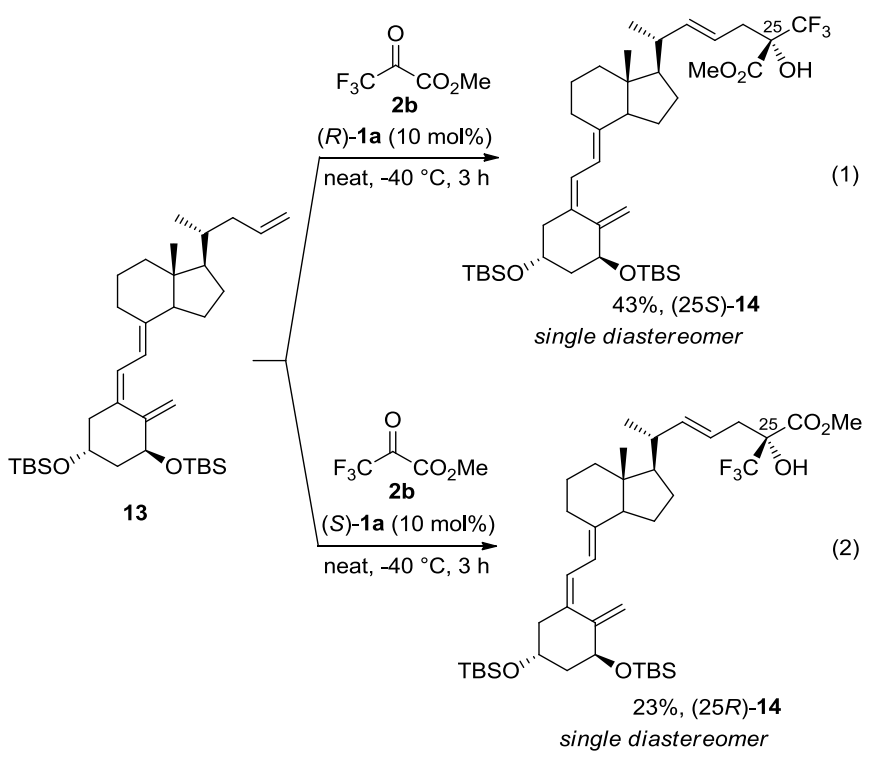

Scheme 6.

The steroidal trifluoropyruvate-ene products along with the further transformed trifluoromethyl analogues of carcitriol lactone were subjected to the biological tests generally executed for vitamin $D$ analogues such as agonist activities for human osteocalcin and VDR (vitamin D receptor) binding affinity for human vitamin $\mathrm{D}$ hormone receptor. VDR Binding affinity and agonist $\left(\mathrm{EC}_{50}(\mathrm{nM})\right)$ activity thus obtained are tabularized in Table $2{ }^{23}$ Interestingly, the steroidal ene products themselves, namely the unsaturated trifluoromethyl analogues of not only (25S)-methyl ester but also (25R)-methyl ester show significantly high agonist activity (ten times and two hundred ten times active, respectively) even with only half level of binding affinity with VDR (1/1.8 and 1/1.6, respectively). Particularly, the (25R)$\Delta_{22(23)}$-methyl ester show remarkable high agonist activity $\left(\mathrm{EC}_{50}\right.$ $0.003 \mathrm{nM}$ ) with two order of magnitude than the parent 1,25dihydroxy vitamin $\mathrm{D}_{3}\left(\mathrm{EC}_{50} 0.638 \mathrm{nM}\right)$.

Table 2.

\begin{tabular}{c} 
VDR Binding Affinity \\
$\begin{array}{c}\text { agonist } \\
\mathrm{EC}_{50}(\mathrm{nM})^{26}\end{array}$ \\
\hline
\end{tabular}

\section{Conclusions}

In summary, we have succeeded in the highly enantioselective trifluoropyruvate-ene reactions with steroid side chain olefins by virtue of the most stable and Lewis acidic $\mathrm{Pd}^{2+}$ catalysts amongst the first and second transition series of divalent metals with bidentate chelate substrates such as trifluoropyruvate. The remarkably high agonist activities of the ene products than the modified trifluoromethyl analogue of e.g. carcitriol lactone. Development of novel and practical reactions to provide optically active $\alpha$-fluoromethyl-substituted tertiary alcohol drugs and their analogues with quaternary carbon centers in this context of latestage fluoromethyl-functinalization is on-going in our laboratory.

\section{Experimental}

\subsection{General}

${ }^{1} \mathrm{H},{ }^{13} \mathrm{C}$, and ${ }^{19} \mathrm{~F}$ NMR spectra were measured on Bruker AV300M (300 MHz) spectrometers. Chemical shifts of ${ }^{1} \mathrm{H}$ NMR were expressed in parts per million relative to the singlet $(\delta=$ 7.26) for $\mathrm{CDCl}_{3}$. Chemical shifts of ${ }^{13} \mathrm{C}$ NMR were expressed in parts per million relative to the central line of the triplet $(\delta=$ 77.0) for $\mathrm{CDCl}_{3}$. Chemical shifts of ${ }^{19} \mathrm{~F} \mathrm{NMR}$ were expressed in parts per million relative to the singlet $(\delta=-63.24)$ for benzotrifluoride (BTF) as an internal standard. Optical rotations were measured on a JASCO P-1020. Mass spectra were measured on a JEOL JMS-T100CS (Accu-TOF) spectrometer. IR spectra were measured on a JASCO FT/IR-4200 spectrometer. High performance liquid chromatography (HPLC) was conducted on JASCO PU-980, LG-980-02, DG-980-50, MD-2010, and CO966 instrument equipped with model UV-975 spectrometers as an ultra violet light. Dichloromethane, toluene, and diethyl ether were purchased from Kanto Chemical Co., Inc. Ethyl trifluoropyruvate was provided from Central Glass Co., Ltd. Silver hexafluoroantimonate was purchased from Aldrich. $\mathrm{PdCl}_{2}[(S)$-BINAP] was synthesized according to the reported procedure.

\subsection{General Procedure for Catalytic Asymmetric Ene} Reaction with Trifluoropyruvate (Table 1, entry 1)

To a solution of $\mathrm{PdCl}_{2}[(S)$-BINAP] $(3.2 \mathrm{mg}, 0.004 \mathrm{mmol})$ and ethyl trifluoropyruvate $\mathbf{2 a}(5.3 \mathrm{~mL}, 40 \mathrm{mmol})$ was added $\mathrm{AgSbF}_{6}$ $(3.0 \mathrm{mg}, 0.0088 \mathrm{mmol})$ at room temperature under argon atmosphere. After stirring for $30 \mathrm{~min}$, isobutene (ca. $0.2 \mathrm{mmol}$ ) was added at $-78{ }^{\circ} \mathrm{C}$. The reaction mixture was stirred at $-20{ }^{\circ} \mathrm{C}$ for $10 \mathrm{~min}$, and then directly loaded onto a short silica-gel column (hexane/AcOEt $=1 / 1$ ) to remove the catalyst. Purification by silica-gel chromatography (hexane/AcOEt $=9 / 1$ ) gave alcohol product $\mathbf{3}^{24}$ The enantiomeric excess was determined by chiral HPLC analysis.

\subsubsection{4-Methyl-2-hydroxy-2-trifluoromethylpentano-4-} lactone 6

To a solution of $\mathrm{PdCl}_{2}[(S)$-BINAP] (32 $\mathrm{mg}, 0.04 \mathrm{mmol}$ ) in $\mathrm{CH}_{2} \mathrm{Cl}_{2}(4 \mathrm{~mL})$ was added $\mathrm{AgSbF}_{6}(30.2 \mathrm{mg}, 0.088 \mathrm{mmol})$ at room temperature. After stirring for $30 \mathrm{~min}$, ethyl trifluoropyruvate $\mathbf{2 a}(68 \mathrm{mg}, 0.4 \mathrm{mmol})$ and isobutene $(112 \mathrm{mg}$, $2.0 \mathrm{mmol}$ ) were added to the mixture at $-30{ }^{\circ} \mathrm{C}$. After the reaction mixture was stirred at $-15{ }^{\circ} \mathrm{C}$ for $4 \mathrm{~h}$, warmed up to $80{ }^{\circ} \mathrm{C}$, and stirred for $24 \mathrm{~h}$ to give $38 \%$ of $\mathbf{6}$ after silica-gel chromatography. ${ }^{1} \mathrm{H} \mathrm{NMR}\left(\mathrm{CDCl}_{3}, 300 \mathrm{MHz}\right) \delta 1.54(\mathrm{~s}, 3 \mathrm{H}), 1.59(\mathrm{~s}, 3 \mathrm{H}), 2.38(\mathrm{~d}$, $J=17.7 \mathrm{~Hz}, 1 \mathrm{H}), 2.51(\mathrm{~d}, J=5.0 \mathrm{~Hz}, 1 \mathrm{H}), 3.75(\mathrm{~s}, 1 \mathrm{H}) ;{ }^{13} \mathrm{C}$ $\mathrm{NMR}\left(\mathrm{CDCl}_{3}, 75 \mathrm{MHz}\right) \delta 28.7,29.2,42.4,77.1,83.6,122.9$ (q, $\left.{ }^{1} J_{\mathrm{C}-\mathrm{F}}=285.3 \mathrm{~Hz}\right), 171.1 ;{ }^{19} \mathrm{~F}$ NMR $\left(\mathrm{CDCl}_{3}, 282 \mathrm{MHz}\right) \delta-80.5(\mathrm{~s})$; HRMS (APCI) Calcd for $\mathrm{C}_{7} \mathrm{H}_{8} \mathrm{~F}_{3} \mathrm{O}_{3}$ [M-H] 197.0426, Found: 197.0427 .

4.3.2. (22E,8S,25S)-Des-A,B-8-(tert-Butyldimethylsiloxy)-25hydroxy-27,27,27-trifluoro-26-ethoxycarbonyl-22-cholestene (25S)-5

To a solution of $(R)$-BINAP-PdCl ${ }_{2}(8.0 \mathrm{mg}, 0.01 \mathrm{mmol})$ in $\mathrm{CH}_{2} \mathrm{Cl}_{2}(1 \mathrm{~mL})$ was added $\mathrm{AgSbF}_{6}(7.6 \mathrm{mg}, 0.022 \mathrm{mmol})$ at room 
temperature. After stirring for $30 \mathrm{~min}$, ethyl trifluoropyruvate 2a (34 mg, $0.2 \mathrm{mmol})$ and $\mathbf{4}(33.7 \mathrm{mg}, 0.1 \mathrm{mmol})$ were added to the mixture at $-20{ }^{\circ} \mathrm{C}$. After the reaction mixture was stirred at that temperature for $3 \mathrm{~h}$, triethylamine $(25 \mu \mathrm{L})$ was added at that temperature. The solution was then quenched with sat. $\mathrm{NaHCO}_{3}$ and extracted three times with $\mathrm{Et}_{2} \mathrm{O}$. The combined organic layer was washed with brine, dried over $\mathrm{MgSO}_{4}$ and evaporated under reduced pressure. The resultant residue was purified by silica-gel chromatography (hexane/Et $2 \mathrm{O}=20 / 1$, after hexane only) gave 41 $\mathrm{mg}(81 \%)$ of $(25 S)-5$.

${ }^{1} \mathrm{H}$ NMR $\left(\mathrm{CDCl}_{3}, 300 \mathrm{MHz}\right) \delta-0.008(\mathrm{~s}, 3 \mathrm{H}),-0.006(\mathrm{~s}, 3 \mathrm{H})$, $0.89(\mathrm{~s}, 9 \mathrm{H}), 0.91(\mathrm{~s}, 3 \mathrm{H}), 0.95(\mathrm{~d}, J=6.6 \mathrm{~Hz}, 3 \mathrm{H}), 1.04 \sim 2.08(\mathrm{~m}$, $16 \mathrm{H}), 2.58(\mathrm{t}, J=7.2 \mathrm{~Hz}, 2 \mathrm{H}), 3.75(\mathrm{~s}, 1 \mathrm{H}), 3.99(\mathrm{~d}, J=2.1 \mathrm{~Hz}$, $1 \mathrm{H}), 4.31(\mathrm{t}, J=7.2 \mathrm{~Hz}, 2 \mathrm{H}), 5.20(\mathrm{td}, J=7.2,15.3 \mathrm{~Hz}, 1 \mathrm{H}), 5.43$ $(\mathrm{dd}, J=8.7,15.3 \mathrm{~Hz}, 1 \mathrm{H}) ;{ }^{13} \mathrm{C} \mathrm{NMR}\left(\mathrm{CDCl}_{3}, 75 \mathrm{MHz}\right) \delta-5.2$, 4.9, 13.9, 17.6, 18.0, 20.4, 23.0, 25.8, 27.6, 34.4, 35.0, 39.8, 40.6, $42.1,53.1,56.1,63.5,69.4,77.8\left(\mathrm{q},{ }^{2} J_{\mathrm{C}-\mathrm{F}}=28.5 \mathrm{~Hz}\right), 117.6,123.4$ $\left(\mathrm{q},{ }^{1} J_{\mathrm{C}-\mathrm{F}}=284.3 \mathrm{~Hz}\right), 143.7,169.4 ;{ }^{19} \mathrm{~F} \mathrm{NMR}\left(\mathrm{CDCl}_{3}, 282 \mathrm{MHz}\right)$ $\delta$-78.4 (s); IR (neat, $\mathrm{cm}^{-1}$ ) 3505, 2949, 2861, 1741, 1307, 1242, 1186, 1019, 836; HRMS (ESI-TOF) Calcd for $\mathrm{C}_{26} \mathrm{H}_{45} \mathrm{~F}_{3} \mathrm{O}_{4} \mathrm{Na}_{1} \mathrm{Si}_{1}$ $[\mathrm{M}+\mathrm{Na}]^{+}$529.2937, Found: 529.2932; $[\alpha]_{\mathrm{D}}{ }^{26}+31.8(\mathrm{c}=0.12$ in $\mathrm{CHCl}_{3}$ ).

4.3.3. (22E,8S,25S)-Des-A,B-8-(tert-Butyldimethylsiloxy)-25hydroxy-27,27,27-trifluoro-26-cholestenoic acid (25S)-8

To a solution of $(25 S)-5(152 \mathrm{mg}, 0.3 \mathrm{mmol})$ in a $\mathrm{MeOH} / \mathrm{H}_{2} \mathrm{O}$ (7:3) mixture $(2.5 \mathrm{ml}), 0.5 \mathrm{~N} \mathrm{KOH}(1.81 \mathrm{ml}, 0.91 \mathrm{mmol})$ was added. The reaction mixture was stirred at $65{ }^{\circ} \mathrm{C}$ for $7 \mathrm{~h}$, and $\mathrm{MeOH}$ was removed in vacuo. $1 \mathrm{~N} \mathrm{HCl}$ was added until $\mathrm{pH} 1 \sim 2$ was reached, and the reaction mixture was extract with EtOAc $(3 \times 20 \mathrm{ml})$, dried over $\mathrm{Na}_{2} \mathrm{SO}_{4}$, and evaporated under reduced pressure to give $136 \mathrm{mg}(95 \%)$ of $(25 R)-8$.

${ }^{1} \mathrm{H}$ NMR $\left(\mathrm{CDCl}_{3}, 300 \mathrm{M} \mathrm{Hz}\right) \delta-0.003(\mathrm{~s}, 3 \mathrm{H}),-0.012(\mathrm{~s}, 3 \mathrm{H})$, $0.89(\mathrm{~s}, 9 \mathrm{H}), 0.92(\mathrm{~s}, 3 \mathrm{H}), 0.95(\mathrm{~d}, J=6.6 \mathrm{~Hz}, 3 \mathrm{H}) 1.06 \sim 2.10(\mathrm{~m}$, $15 \mathrm{H}), 2.64(\mathrm{~m}, 2 \mathrm{H}), 4.00(\mathrm{~s}, 1 \mathrm{H}), 5.24(\mathrm{td}, J=7.2,15.3 \mathrm{~Hz}, 1 \mathrm{H})$, $5.51(\mathrm{dd}, J=8.7,15.3 \mathrm{~Hz}, 1 \mathrm{H}) ;{ }^{13} \mathrm{C} \mathrm{NMR}\left(\mathrm{CDCl}_{3}, 75 \mathrm{MHz}\right) \delta-$ 5.2, -4.9, 13.9, 17.6, 18.0, 20.3, 23.0, 25.8, 27.7, 34.4, 35.2, 39.9, $40.6,42.1,53.1,56.0,69.4,77.9\left(\mathrm{q},{ }^{2} J_{\mathrm{C}-\mathrm{F}}=28.5 \mathrm{~Hz}\right), 116.9,123.1$ $\left(\mathrm{q},{ }^{1} J_{\mathrm{C}-\mathrm{F}}=284.5 \mathrm{~Hz}\right), 144.9,173.4 ;{ }^{19} \mathrm{~F} \mathrm{NMR}\left(\mathrm{CDCl}_{3}, 282 \mathrm{MHz}\right)$ $\delta$-78.1 (s); IR (neat, $\mathrm{cm}^{-1}$ ) 3412, 2938, 2855, 1727, 1248, 1181.

HRMS (APCI) Calcd for $\mathrm{C}_{24} \mathrm{H}_{41} \mathrm{~F}_{3} \mathrm{O}_{4} \mathrm{Na}_{1} \mathrm{Si}_{1}[\mathrm{M}+\mathrm{Na}]^{+}$501.2624, Found: 501.2615; $[\alpha]_{\mathrm{D}}{ }^{27}+28.6\left(\mathrm{c}=0.21\right.$ in $\left.\mathrm{CHCl}_{3}\right)$.

4.3.4. (8S,22S,23S,25S)-Des-A,B-8-(tert-Butyldimethylsiloxy)22-iodo-25-hydroxy-25-trifluoromethylcholestane-26,23lactone $(22 S, 23 R, 25 S)-9$

A solution of $(25 S)-8(23.9 \mathrm{mg}, 0.05 \mathrm{mmol})$ and 2,4,6-collidine $(9.9 \mu \mathrm{l}, 0.075 \mathrm{mmol})$ in $\mathrm{Et}_{2} \mathrm{O}(3.6 \mathrm{ml})$ was stirred at room temperature for $30 \mathrm{~min}$, the mixture was cooled to $-30{ }^{\circ} \mathrm{C}$, and then $\mathrm{I}_{2}(38.1 \mathrm{mg}, 0.15 \mathrm{mmol})$ was added. After $24 \mathrm{~h}$, the mixture was diluted with $\mathrm{CHCl}_{3}$, washed with aq. $\mathrm{Na}_{2} \mathrm{~S}_{2} \mathrm{O}_{3}$ and brine, dried over $\mathrm{Na}_{2} \mathrm{SO}_{4}$, and evaporated under reduced pressure. The resultant residue was purified by silica-gel chromatography to give $26.0 \mathrm{mg}(86 \%)$ of $(22 S, 23 S, 25 S)-9$.

${ }^{1} \mathrm{H}$ NMR $\left(\mathrm{CDCl}_{3}, 300 \mathrm{MHz}\right) \delta 0.00(\mathrm{~s}, 3 \mathrm{H}), 0.01(\mathrm{~s}, 3 \mathrm{H}), 0.89$ (s, $9 \mathrm{H}), 0.94(\mathrm{~d}, J=6.0 \mathrm{~Hz}, 3 \mathrm{H}), 1.01(\mathrm{~s}, 3 \mathrm{H}), 1.12 \sim 1.95(\mathrm{~m}, 14 \mathrm{H})$, $2.28(\mathrm{dd}, J=9.0,14.4 \mathrm{~Hz}, 1 \mathrm{H}), 3.18(\mathrm{dd}, J=6.0,14.4 \mathrm{~Hz}, 1 \mathrm{H})$, $4.01(\mathrm{~d}, J=2.4 \mathrm{~Hz}, 1 \mathrm{H}), 4.10(\mathrm{dd}, J=1.5,10.5 \mathrm{~Hz}, 1 \mathrm{H}), 4.75$ (ddd, $J=6.0,9.010 .5 \mathrm{~Hz}, 1 \mathrm{H}) ;{ }^{13} \mathrm{C} \mathrm{NMR}\left(\mathrm{CDCl}_{3}, 75 \mathrm{MHz}\right) \delta$ 5.2, -4.9, 1.0, 15.0, 16.1, 17.6, 18.0, 22.8, 25,8, 26.3, 34.3, 36.6, $39.3,40.7,42.2,48.9,52.9,56.3,69.3,76.2\left(\mathrm{q},{ }^{2} J_{\mathrm{C}-\mathrm{F}}=31.8 \mathrm{~Hz}\right)$, $123.0\left(\mathrm{q},{ }^{1} J_{\mathrm{C}-\mathrm{F}}=283.4 \mathrm{~Hz}\right), 170.9 ;{ }^{19} \mathrm{~F} \mathrm{NMR}\left(\mathrm{CDCl}_{3}, 282 \mathrm{MHz}\right)$ $\delta$-80.2 (s); IR (neat, $\mathrm{cm}^{-1}$ ) 3416, 2949, 2855, 1770, 1460, 1212. HRMS (APCI) Calcd for $\mathrm{C}_{24} \mathrm{H}_{41} \mathrm{~F}_{3} \mathrm{I}_{1} \mathrm{O}_{4} \mathrm{Si}_{1}[\mathrm{M}+\mathrm{H}]^{+}$605.1771, Found: 605.1756; $[\alpha]_{\mathrm{D}}^{27}-0.89\left(\mathrm{c}=0.11\right.$ in $\left.\mathrm{CHCl}_{3}\right)$.
4.3.5. (8S,23S,25S)-Des-A,B-8-(tert-Butyldimethylsiloxy)-25hydroxy-25-trifluoromethylcholestane-26,23-lactone $(22 S, 25 S)-7$

To a solution of $(22 S, 23 S, 25 S)-9(125 \mathrm{mg}, 0.21 \mathrm{mmol})$ in benzene $(7.9 \mathrm{ml})$ was added $n-\mathrm{BuSnH}(110 \mu \mathrm{l}, 0.42 \mathrm{mmol})$ and AIBN (6.9 mg, $0.042 \mathrm{mmol})$. The reaction mixture was stirred for $3 \mathrm{~min}$ at $65{ }^{\circ} \mathrm{C}$, and diluted with $\mathrm{Et}_{2} \mathrm{O}$. The reaction mixture was washed with brine, and dried over $\mathrm{MgSO}_{4}$ and evaporated under reduced pressure. The resultant residue was purified by silica-gel chromatography to give $100 \mathrm{mg}(89 \%)$ of $(23 S, 25 S)-7$. ${ }^{1} \mathrm{H} \mathrm{NMR}\left(\mathrm{CDCl}_{3}, 300 \mathrm{MHz}\right) \delta-0.002(\mathrm{~s}, 3 \mathrm{H}), 0.01(\mathrm{~s}, 3 \mathrm{H}), 0.89$ (s, 9H), $0.94(\mathrm{~s}, 3 \mathrm{H}), 0.98(\mathrm{~d}, J=6.6 \mathrm{~Hz}, 3 \mathrm{H}), 1.13 \sim 1.89(\mathrm{~m}$, $14 \mathrm{H}), 1.97(\mathrm{td}, J=2.7,12.3 \mathrm{~Hz}, 1 \mathrm{H}), 2.12(\mathrm{dd}, J=9.3,14.4 \mathrm{~Hz}$, $1 \mathrm{H}), 2.86(\mathrm{dd}, J=6.0,14.4 \mathrm{~Hz}, 1 \mathrm{H}), 3.43(\mathrm{~s}, 1 \mathrm{H}), 4.00(\mathrm{~d}, J=2.4$ $\mathrm{Hz}, 1 \mathrm{H}), 4.60 \sim 4.69(\mathrm{~m}, 1 \mathrm{H}) ;{ }^{13} \mathrm{C} \mathrm{NMR}\left(\mathrm{CDCl}_{3}, 75 \mathrm{MHz}\right) \delta-5.2$, -4.9, 13.7, 17.6, 18.0, 18.5, 23.0, 25.8(2C), 27.3, 32.5, 34.4, 37.7, $40.7,42.3,42.8,53.1,69.3,76.1\left(\mathrm{q},{ }^{2} J_{\mathrm{C}-\mathrm{F}}=31.5 \mathrm{~Hz}\right), 123.3(\mathrm{q}$, $\left.{ }^{1} J_{\mathrm{C}-\mathrm{F}}=283.4 \mathrm{~Hz}\right), 171.5 ;{ }^{19} \mathrm{~F} \mathrm{NMR}\left(\mathrm{CDCl}_{3}, 282 \mathrm{MHz}\right) \delta-80.2(\mathrm{~s})$; IR (neat, $\mathrm{cm}^{-1}$ ) 3438, 2943, 2861, 1787, 1466, 1202, 1162, 834; HRMS (APCI) Calcd for $\mathrm{C}_{24} \mathrm{H}_{40} \mathrm{~F}_{3} \mathrm{O}_{4} \mathrm{Si}_{1}$ [M-H] 477.2645, Found: 477.2656; $[\alpha]_{\mathrm{D}}{ }^{26}+24.6\left(\mathrm{c}=0.18\right.$ in $\left.\mathrm{CHCl}_{3}\right)$.

4.3.6. (8S,23S,25S)-Des-A,B-8,25-Dihydroxy-25-trifluoromethylcholestane-26,23-lactone $(23 S, 25 S)-10$ '

To a solution of $(23 S, 25 S)-7(100 \mathrm{mg}, 0.21 \mathrm{mmol})$ in $\mathrm{MeOH}(4.2$ ml) was added $p$-TsOH $(47.0 \mathrm{mg}, 0.27 \mathrm{mmol})$ and the resulting mixture was stirred for $12 \mathrm{~h}$ at $65^{\circ} \mathrm{C}$. The reaction mixture was diluted with AcOEt and sat. $\mathrm{NaHCO}_{3}$ was added. The resulting mixture was extracted with AcOEt. The organic layer was washed with brine, dried over $\mathrm{MgSO}_{4}$, filtered and concentrated under reduced pressure. The resultant residue was purified by silica-gel chromatography to give $76.5 \mathrm{mg}(92 \%)$ of $(23 S, 25 S)$ 10 '.

${ }^{1} \mathrm{H} \mathrm{NMR}\left(\mathrm{CDCl}_{3}, 300 \mathrm{MHz}\right) \delta 0.94(\mathrm{~s}, 3 \mathrm{H}), 0.98(\mathrm{~d}, J=6.6 \mathrm{~Hz}$, $3 \mathrm{H}), 1.05 \sim 1.90(\mathrm{~m}, 15 \mathrm{H}), 2.00(\mathrm{~d}, J=12.9 \mathrm{~Hz}, 1 \mathrm{H}), 2.11(\mathrm{dd}, J=$ 9.3, 14.1 Hz, 1H), $2.85(\mathrm{dd}, J=6.3,14.1 \mathrm{~Hz}, 1 \mathrm{H}), 4.08(\mathrm{~s}, 1 \mathrm{H})$, 4.47 (bs, $1 \mathrm{H}), 4.63(\mathrm{~d}, J=8.1 \mathrm{~Hz}, 1 \mathrm{H}) ;{ }^{13} \mathrm{C} \mathrm{NMR}\left(\mathrm{CDCl}_{3}, 75\right.$ MHz) $\delta 13.5,17.3,18.4,22.4,27.2,32.5,33.4,37.7,40.4,42.0$, $42.8,52.5,56.8,69.3,75.8,76.0\left(\mathrm{q},{ }^{2} J_{\mathrm{C}-\mathrm{F}}=31.5 \mathrm{~Hz}\right), 123.3(\mathrm{q}$, $\left.{ }^{1} J_{\mathrm{C}-\mathrm{F}}=283.4 \mathrm{~Hz}\right), 171.6 ;{ }^{19} \mathrm{~F} \mathrm{NMR}\left(\mathrm{CDCl}_{3}, 282 \mathrm{MHz}\right) \delta-80.1(\mathrm{~s})$. IR (neat, $\mathrm{cm}^{-1}$ ) 3450, 2932, 1782, 1457, 1193; HRMS (APCI) Calcd for $\mathrm{C}_{18} \mathrm{H}_{26} \mathrm{~F}_{3} \mathrm{O}_{4}[\mathrm{M}-\mathrm{H}]^{-} 363.1783$, Found: $367.1776 ;[\alpha]_{\mathrm{D}}{ }^{25}$ $+35.5\left(\mathrm{c}=0.11\right.$ in $\left.\mathrm{CHCl}_{3}\right)$.

4.3.7. (23S,25S)-Des-A,B-25-Hydroxy-25-trifluoromethylcholestane-8-one-26,23-lactone $(23 S, 25 S)$-10

To a solution of $(23 S, 25 S)-10$ ' $(76.5 \mathrm{mg}, 0.21 \mathrm{mmol})$ in $\mathrm{CH}_{2} \mathrm{Cl}_{2}$ $(4.2 \mathrm{ml})$ was added tetra- $n$-propylammonium perruthenate $(7.4$ $\mathrm{mg}, 0.021 \mathrm{mmol})$, 4-methylmorpholine $\mathrm{N}$-oxide $(98.4 \mathrm{mg}, 0.84$ mmol) and powdered molecular sieves $4 \mathrm{~A}$ at $0{ }^{\circ} \mathrm{C}$. The mixture was stirred for $2 \mathrm{~h}$ at the temperature and loaded on silica-gel chromatography to give $65.4 \mathrm{mg}(86 \%)$ of $(23 S, 25 S)$-10.

${ }^{1} \mathrm{H} \mathrm{NMR}\left(\mathrm{CDCl}_{3}, 300 \mathrm{MHz}\right) \delta 0.64(\mathrm{~s}, 3 \mathrm{H}), 1.03(\mathrm{~d}, J=6.3 \mathrm{~Hz}$, $3 \mathrm{H}), 1.24 \sim 2.32(\mathrm{~m}, 15 \mathrm{H}), 2.44(\mathrm{dd}, J=7.5,11.4 \mathrm{~Hz}, 1 \mathrm{H}), 2.86$ $(\mathrm{dd}, J=6.3,14.4 \mathrm{~Hz}, 1 \mathrm{H}), 4.29(\mathrm{~s}, 1 \mathrm{H}), 4.59 \sim 4.67(\mathrm{~m}, 1 \mathrm{H}) ;{ }^{13} \mathrm{C}$ NMR $\left(\mathrm{CDCl}_{3}, 75 \mathrm{MHz}\right) \delta 12.5,18.5,19.1,23.9,27.4,32.6,37.7$, $38.9,40.8,42.7,49.9,56.7,61.8,75.5,75.9\left(\mathrm{q},{ }^{2} J_{\mathrm{C}-\mathrm{F}}=31.6 \mathrm{~Hz}\right)$, $123.1\left(\mathrm{q},{ }^{1} J_{\mathrm{C}-\mathrm{F}}=288.8 \mathrm{~Hz}\right), 171.2,212.3 ;{ }^{19} \mathrm{~F} \mathrm{NMR}\left(\mathrm{CDCl}_{3}, 282\right.$ MHz) $\delta$-80.1 (s); IR (neat, $\mathrm{cm}^{-1}$ ) 3439, 2945, 2850, 1778, 1694, 1406, 1150; HRMS (APCI) Calcd for $\mathrm{C}_{18} \mathrm{H}_{24} \mathrm{~F}_{3} \mathrm{O}_{4}[\mathrm{M}-\mathrm{H}]^{-}$ 361.1627, Found: $361.1313 ;[\alpha]_{\mathrm{D}}{ }^{26}+11.9\left(\mathrm{c}=0.17\right.$ in $\left.\mathrm{CHCl}_{3}\right)$.

4.3.8. (23S,25S)-Des-A,B-8-Bromomethylidene-25-hydroxy25-trifluoromethylcholestane-26,23-lactone (23S,25S)-11

To a solution of bromomethyltriphenylphosphonium bromide (393 $\mathrm{mg}, 0.9 \mathrm{mmol})$ in toluene $(2.4 \mathrm{ml})$ was added lithium 
hexamethyldisilazane $(151 \mathrm{mg}, 0.9 \mathrm{mmol})$ at $-78{ }^{\circ} \mathrm{C}$, and the mixture was warmed up to $0{ }^{\circ} \mathrm{C}$ and stirred for $10 \mathrm{~min}$. After cooling to $-78{ }^{\circ} \mathrm{C}$, to the resulting solution was added $(23 S, 25 S)$ $10(65.4 \mathrm{mg}, 0.18 \mathrm{mmol})$ in toluene $(1.2 \mathrm{ml})$ dropwise, and the mixture was stirred at $-30{ }^{\circ} \mathrm{C}$ for $2 \mathrm{~h}$. To the reaction mixture was added sat. $\mathrm{NH}_{4} \mathrm{Cl}$. The resulting mixture was warmed up to room temperature and extracted with AcOEt. The organic layer was washed with brine, dried over $\mathrm{MgSO}_{4}$, filtered and concentrated under reduced pressure. The resultant residue was purified by silica-gel chromatography to give $6.8 \mathrm{mg}(0.016 \mathrm{mmol}, 18 \%)$ of (23S,25S)-11.

${ }^{1} \mathrm{H}$ NMR $\left(\mathrm{CDCl}_{3}, 300 \mathrm{MHz}\right) \delta 0.60(\mathrm{~s}, 3 \mathrm{H}), 1.03(\mathrm{~d}, J=6.6 \mathrm{~Hz}$, $3 \mathrm{H}), 1.19 \sim 2.05(\mathrm{~m}, 15 \mathrm{H}), 2.13(\mathrm{ddd}, J=1.2,9.3,14.4 \mathrm{~Hz}, 1 \mathrm{H})$, $2.88(\mathrm{dd}, J=6.3,14.4 \mathrm{~Hz}, 1 \mathrm{H}), 4.60 \sim 4.69(\mathrm{~m}, 1 \mathrm{H}), 5.66(\mathrm{~s}, 1 \mathrm{H})$, $5.95(\mathrm{~s}, 1 \mathrm{H}) ;{ }^{19} \mathrm{~F} \mathrm{NMR}\left(\mathrm{CDCl}_{3}, 282 \mathrm{MHz}\right) \delta-80.2$ (s); IR (neat, $\mathrm{cm}^{-1}$ ) 3433, 3087, 2938, 2860, 1782, 1718, 1172; HRMS (APCI) Calcd for $\mathrm{C}_{19} \mathrm{H}_{25} \mathrm{Br}_{1} \mathrm{~F}_{3} \mathrm{O}_{3}[\mathrm{M}-\mathrm{H}]^{-}$439.0919, Found: 439.0939; $[\alpha]_{\mathrm{D}}^{25}+74.3\left(\mathrm{c}=0.11\right.$ in $\left.\mathrm{CHCl}_{3}\right)$.

\subsubsection{5-Trifluoromethyl-1 $\alpha, 25$-dihydroxy-26,23-carcitriol} lactone $(23 S, 25 S)-12$

To a solution of A-ring precursor enyne $(4.0 \mathrm{mg}, 0.01 \mathrm{mmol})$ and $(23 S, 25 S)-11(3.2 \mathrm{mg}, 0.0073 \mathrm{mmol})$ in toluene/ $\mathrm{NEt}_{3}(730 \mu \mathrm{l}$, toluene $\left./ \mathrm{NEt}_{3}=1: 3\right)$ were added $\mathrm{Pd}\left(\mathrm{PPh}_{3}\right)_{4}(2.5 \mathrm{mg}, 0.002$ $\mathrm{mmol}$ ), and the mixture was stirred at $110{ }^{\circ} \mathrm{C}$ for $4 \mathrm{~h}$, according to the reported procedure. ${ }^{20}$ The mixture was filtered through a silica-gel pad, and concectrated. The residue was subjected to silica-gel preparative TLC to give crude mixture of the protected derivative $(3.0 \mathrm{mg}, 56 \%)$. To the crude mixture dissolved in THF $(273 \mu \mathrm{l})$, was added $\mathrm{HF} / \mathrm{Py}(70 \%, 116 \mu \mathrm{l})$ at $0{ }^{\circ} \mathrm{C}$, and stirred for $2 \mathrm{~h}$. To the mixture was added sat. $\mathrm{NH}_{4} \mathrm{Cl}$. The resulting mixture was warmed up to room temperature and extracted with AcOEt, dried over $\mathrm{MgSO}_{4}$, filtered and concentrated under reduced pressure. The resultant residue was purified by silica-gel chromatography to give $0.7 \mathrm{mg}$ (34\%) of $(23 S, 25 S)-12$.

${ }^{1} \mathrm{H}$ NMR $\left(\mathrm{CDCl}_{3}, 300 \mathrm{MHz}\right) \delta 0.58(\mathrm{~s}, 3 \mathrm{H}), 1.02(\mathrm{~d}, J=6.6 \mathrm{~Hz}$, $3 \mathrm{H}), 1.23 \sim 1.75+1.83 \sim 2.10(\mathrm{~m}, 22 \mathrm{H}), 2.28 \sim 2.35(\mathrm{~m}, 1 \mathrm{H}), 2.60$ $(\mathrm{dd}, J=0.9,11.1 \mathrm{~Hz}, 1 \mathrm{H}), 2.83 \sim 2.86(\mathrm{~m}, 1 \mathrm{H}), 4.22 \sim 4.24(\mathrm{~m}$, $1 \mathrm{H}), 4.43 \sim 4.44(\mathrm{~m}, 1 \mathrm{H}), 5.00(\mathrm{~s}, 1 \mathrm{H}), 5.34(\mathrm{~s}, 1 \mathrm{H}), 6.00(\mathrm{~d}, J=$ $11.4 \mathrm{~Hz}, 1 \mathrm{H}), 6.37(\mathrm{~d}, J=11.7 \mathrm{~Hz}, 1 \mathrm{H}) ;{ }^{19} \mathrm{~F} \mathrm{NMR}\left(\mathrm{CDCl}_{3}, 282\right.$ MHz) $\delta$-80.2 (s); HRMS (APCI) Calcd for $\mathrm{C}_{27} \mathrm{H}_{36} \mathrm{~F}_{3} \mathrm{O}_{5}[\mathrm{M}-\mathrm{H}]$ 497.2515, Found: 497.2535; $[\alpha]_{\mathrm{D}}^{25}+26.5\left(\mathrm{c}=0.04\right.$ in $\left.\mathrm{CHCl}_{3}\right)$.

\subsubsection{Steroid olefin 13}

To a solution of methyltriphenylphosphonium bromide $(61 \mathrm{mg}$, $0.17 \mathrm{mmol})$ in THF $(0.9 \mathrm{ml})$ was added $n$-BuLi $(0.11 \mathrm{ml}$ of a 1.35 $\mathrm{M}$ solution in hexane, $0.15 \mathrm{mmol}$ ) at $0{ }^{\circ} \mathrm{C}$. After the mixture was stirred for $1 \mathrm{~h}$, a solution of calcitroic aldehyde $(29.4 \mathrm{mg}, 0.05$ $\mathrm{mmol})$ in THF $(0.2 \mathrm{ml})$ was added slowly. The resulting mixture was stirred at $0{ }^{\circ} \mathrm{C}$ for $30 \mathrm{~min}$ and quenched by sat. $\mathrm{NH}_{4} \mathrm{Cl}$. The mixture was extracted with $\mathrm{Et}_{2} \mathrm{O}$, washed with brine, dried over $\mathrm{Na}_{2} \mathrm{SO}_{4}$, and evaporated under reduced pressure. The resultant residue was purified by silica-gel chromatography to give 25.2 $\mathrm{mg}(86 \%)$ of $\mathbf{1 3}$.

${ }^{1} \mathrm{H}$ NMR $\left(\mathrm{CDCl}_{3}, 300 \mathrm{MHz}\right) \delta 0.060 \sim 0.064(\mathrm{~m}, 12 \mathrm{H}), 0.54(\mathrm{~s}$, $3 \mathrm{H}), 0.85 \sim 0.88(\mathrm{~m}, 18 \mathrm{H}), 0.93(\mathrm{~d}, J=6.6 \mathrm{~Hz}, 3 \mathrm{H}), 1.26 \sim 2.27(\mathrm{~m}$, $17 \mathrm{H}), 2.46(\mathrm{dd}, J=3.9,13.2 \mathrm{~Hz}, 1 \mathrm{H}), 2.82(\mathrm{~d}, J=10.5 \mathrm{~Hz}, 1 \mathrm{H})$, $4.15 \sim 4.23(\mathrm{~m}, 1 \mathrm{H}), 4.36 \sim 4.39(\mathrm{~m}, 1 \mathrm{H}), 4.86(\mathrm{~d}, J=2.4 \mathrm{~Hz}, 1 \mathrm{H})$, $4.97(\mathrm{~s}, 1 \mathrm{H}), 5.01(\mathrm{~d}, J=3.3 \mathrm{~Hz}, 1 \mathrm{H}), 5.18(\mathrm{~d}, J=1.5 \mathrm{~Hz}, 1 \mathrm{H})$, $5.71 \sim 5.85(\mathrm{~m}, 1 \mathrm{H}), 6.02(\mathrm{~d}, J=11.4 \mathrm{~Hz}, 1 \mathrm{H}), 6.24(\mathrm{~d}, J=11.1$ $\mathrm{Hz}, 1 \mathrm{H}$ ); HRMS (APCI) Calcd for $\mathrm{C}_{36} \mathrm{H}_{65} \mathrm{O}_{2} \mathrm{Si}_{2}[\mathrm{M}+\mathrm{H}]^{+}$ 585.4523, Found: 585.4544 .

4.3.11. (25S)-Trifluoromethyl-1 $\alpha, 3 \beta$-bis(tert-butyldimethylsilyloxy)-22-dehydrocarcitriol methyl ester (25S)-14
To a solution of $(R)$-BINAP-PdCl $2(9.6 \mathrm{mg}, 0.012 \mathrm{mmol})$ in $\mathrm{CH}_{2} \mathrm{Cl}_{2}(1 \mathrm{~mL})$ was added $\mathrm{AgSbF}_{6}(8.2 \mathrm{mg}, 0.024 \mathrm{mmol})$ at room temperature. After stirring for $30 \mathrm{~min}$, the solution was added to a mixture of methyl trifluoropyruvate $\mathbf{2 b}(337 \mu \mathrm{l}, 3 \mathrm{mmol})$ and $\mathbf{1 3}$ (17.6 mg, $0.03 \mathrm{mmol}$ ) at $-40{ }^{\circ} \mathrm{C}$ for $2.5 \mathrm{~h}$. The solution was quenched by sat. $\mathrm{NaHCO}_{3}$ and extracted three times with $\mathrm{Et}_{2} \mathrm{O}$. The combined organic layer was washed with brine, dried over $\mathrm{MgSO}_{4}$ and evaporated under reduced pressure. The resultant residue was purified by silica-gel chromatography to give $5.1 \mathrm{mg}$ $(43 \%)$ of $(25 S)-14$.

${ }^{1} \mathrm{H}$ NMR $\left(\mathrm{CDCl}_{3}, 300 \mathrm{MHz}\right) \delta 0.04 \sim 0.06(\mathrm{~m}, 12 \mathrm{H}), 0.53(\mathrm{~s}, 3 \mathrm{H})$, $0.87 \sim 0.88 \quad(\mathrm{~m}, \quad 18 \mathrm{H}), 0.98(\mathrm{~d}, J=6.6 \mathrm{~Hz}, 3 \mathrm{H})$, $1.23 \sim 1.33+1.41 \sim 2.05(\mathrm{~m}, 13 \mathrm{H}), 2.17 \sim 2.27(\mathrm{~m}, 2 \mathrm{H}), 2.45(\mathrm{dd}, J=$ $3.6,9.9 \mathrm{~Hz}, 1 \mathrm{H}), 2.57 \sim 2.62(\mathrm{~m}, 2 \mathrm{H}), 2.83(\mathrm{~d}, J=10.8 \mathrm{~Hz}, 1 \mathrm{H})$, $3.73(\mathrm{~s}, 1 \mathrm{H}), 3.88(\mathrm{~s}, 3 \mathrm{H}), 4.17 \sim 4.22(\mathrm{~m}, 1 \mathrm{H}), 4.36 \sim 4.39(\mathrm{~m}, 1 \mathrm{H})$, $4.86(\mathrm{~d}, J=2.1 \mathrm{~Hz}, 1 \mathrm{H}), 5.18(\mathrm{~d}, J=1.5 \mathrm{~Hz}, 1 \mathrm{H}), 5.21 \sim 5.28(\mathrm{~m}$, $1 \mathrm{H}), 5.46(\mathrm{dd}, J=8.7,15.3 \mathrm{~Hz}, 1 \mathrm{H}), 6.01(\mathrm{~d}, J=11.1 \mathrm{~Hz}, 1 \mathrm{H})$, $6.22(\mathrm{~d}, J=11.4 \mathrm{~Hz}, 1 \mathrm{H}) ;{ }^{19} \mathrm{~F}$ NMR $\left(\mathrm{CDCl}_{3}, 282 \mathrm{MHz}\right) \delta-78.3$ (s); HRMS (APCI) Calcd for $\mathrm{C}_{40} \mathrm{H}_{68} \mathrm{~F}_{3} \mathrm{O}_{5} \mathrm{Si}_{2}[\mathrm{M}+\mathrm{H}]^{+}$741.4558, Found: 741.4558.

4.3.12. (25R)-Trifluoromethyl-1 $\alpha, 3 \beta$-bis(tert-butyldimethylsilyloxy)-22-dehydrocarcitriol methyl ester (25R)-14

(25R)-14 was synthesized in $23 \%$ yield according to a similar manner to that of $(25 S)-\mathbf{1 4}$.

${ }^{1} \mathrm{H}$ NMR $\left(\mathrm{CDCl}_{3}, 300 \mathrm{MHz}\right) \delta 0.02 \sim 0.04(\mathrm{~m}, 12 \mathrm{H}), 0.60(\mathrm{~s}, 3 \mathrm{H})$, $0.80 \sim 0.89(\mathrm{~m}, 18 \mathrm{H}), 1.02(\mathrm{~d}, J=6.6 \mathrm{~Hz}, 3 \mathrm{H}), 1.15 \sim 1.34$ and $1.45 \sim 1.67(\mathrm{~m}, 13 \mathrm{H}), 2.06 \sim 2.25(\mathrm{~m}, 2 \mathrm{H}), 2.45(\mathrm{dd}, J=1.2,9.9$ $\mathrm{Hz}, 1 \mathrm{H}), 2.59 \sim 2.63(\mathrm{~m}, 2 \mathrm{H}), 2.83$ (d, $J=13.5 \mathrm{~Hz}, 1 \mathrm{H}), 3.74$ (s, $1 \mathrm{H}), 3.88(\mathrm{~s}, 3 \mathrm{H}), 4.18 \sim 4.21(\mathrm{~m}, 1 \mathrm{H}), 4.34 \sim 4.47(\mathrm{~m}, 1 \mathrm{H}), 4.86(\mathrm{~d}$, $J=2.4 \mathrm{~Hz}, 1 \mathrm{H}), 5.17(\mathrm{~s}, 1 \mathrm{H}), 5.20 \sim 5.30(\mathrm{~m}, 1 \mathrm{H}), 5.42 \sim 5.47(\mathrm{~m}$, $1 \mathrm{H}), 6.01(\mathrm{~d}, J=11.4 \mathrm{~Hz}, 1 \mathrm{H}), 6.22(\mathrm{~d}, J=10.8 \mathrm{~Hz}, 1 \mathrm{H}) ;{ }^{19} \mathrm{~F}$ $\mathrm{NMR}\left(\mathrm{CDCl}_{3}, 282 \mathrm{MHz}\right) \delta-78.4(\mathrm{~s})$.

4.3.13. (25S)-Trifluoromethyl-22-dehydrocarcitriol (25S)-14' To a solution of $(25 S)-14(3.2 \mathrm{mg}, 0.0043 \mathrm{mmol})$ in THF $(0.3 \mathrm{ml})$ was added HF/Py $(0.13 \mathrm{ml})$ at $0{ }^{\circ} \mathrm{C}$, and stirred for $4 \mathrm{~h}$. To the mixture was added sat. $\mathrm{NaHCO}_{3}$, washed with brine, extracted by AcOEt, dried over $\mathrm{MgSO}_{4}$ and concentrated. The residue was purified by silica-gel chromatography to give (25S)-14' $(1.4 \mathrm{mg}$, $62 \%)$.

${ }^{1} \mathrm{H}$ NMR $\left(\mathrm{CDCl}_{3}, 300 \mathrm{MHz}\right) \delta 0.58(\mathrm{~s}, 3 \mathrm{H}), 0.83 \sim 0.90(\mathrm{~m}, 4 \mathrm{H})$, $0.99(\mathrm{~d}, J=6.3 \mathrm{~Hz}, 3 \mathrm{H}), 1.25 \sim 2.07(\mathrm{~m}, 13 \mathrm{H}), 2.27 \sim 2.34(\mathrm{~m}, 3 \mathrm{H})$, $3.05(\mathrm{~d}, J=7.5 \mathrm{~Hz}, 1 \mathrm{H}), 3.76(\mathrm{~s}, 1 \mathrm{H}), 3.86(\mathrm{~s}, 3 \mathrm{H}), 4.20 \sim 4.23(\mathrm{~m}$, $1 \mathrm{H}), 4.40 \sim 4.42(\mathrm{~m}, 1 \mathrm{H}), 5.00(\mathrm{~s}, 1 \mathrm{H}), 5.21 \sim 5.28(\mathrm{~m}, 1 \mathrm{H}), 5.32(\mathrm{~s}$, $1 \mathrm{H}), 5.45(\mathrm{dd}, J=8.7,15.6 \mathrm{~Hz}, 1 \mathrm{H}), 6.01(\mathrm{~d}, J=10.8 \mathrm{~Hz}, 1 \mathrm{H})$, $6.37(\mathrm{~d}, J=11.4 \mathrm{~Hz}, 1 \mathrm{H}) ;{ }^{19} \mathrm{~F}$ NMR $\left(\mathrm{CDCl}_{3}, 282 \mathrm{MHz}\right) \delta-78.3$ (s).

4.3.14. (25R)-Trifluoromethyl--22-dehydrocarcitriol (25R)14 '

(25R)-14' was synthesized in $56 \%$ yield according to a similar manner to that of (25S)-14'.

${ }^{1} \mathrm{H} \mathrm{NMR}\left(\mathrm{CDCl}_{3}, 300 \mathrm{MHz}\right) \delta 0.54(\mathrm{~s}, 3 \mathrm{H}), 0.83 \sim 0.88(\mathrm{~m}, 4 \mathrm{H})$, $1.00(\mathrm{~d}, J=6.0 \mathrm{~Hz}, 3 \mathrm{H}), 1.23 \sim 2.06(\mathrm{~m}, 13 \mathrm{H}), 2.27 \sim 2.34(\mathrm{~m}, 1 \mathrm{H})$, $2.58 \sim 2.63(\mathrm{~m}, 2 \mathrm{H}), 2.83(\mathrm{~d}, J=15.3 \mathrm{~Hz}, 1 \mathrm{H}), 3.74(\mathrm{~s}, 1 \mathrm{H}), 3.88$ (s, 3H), 4.20 4.22 (m, 1H), 4.40 4.43 (m, 1H), $4.99(\mathrm{~s}, 1 \mathrm{H}), 5.23$ $(\mathrm{dd}, J=7.8,15.9 \mathrm{~Hz}, 1 \mathrm{H}), 5.32(\mathrm{~s}, 1 \mathrm{H}), 5.46(\mathrm{dd}, J=8.7,15.6$ $\mathrm{Hz}, 1 \mathrm{H}), 6.01(\mathrm{~d}, J=11.4 \mathrm{~Hz}, 1 \mathrm{H}), 6.37(\mathrm{~d}, J=11.1 \mathrm{~Hz}, 1 \mathrm{H}) ;{ }^{19} \mathrm{~F}$ $\mathrm{NMR}\left(\mathrm{CDCl}_{3}, 282 \mathrm{MHz}\right) \delta-78.4(\mathrm{~s})$.

\section{Acknowledgments}

This research was supported by Japan Science and Technology Agency (JST) (ACT-C: Creation of Advanced 
Catalytic Transformation for the Sustainable Manufacturing at Low Energy, Low Environmental Load). We are grateful to Prof K. Nagasawa of Tokyo University of Agriculture and Technology and Prof. S. Hatakeyama of Nagasaki University for useful discussion and generous gift of steroidal starting materials. We are grateful to Teijin Pharma Ltd. for the biological tests executed for the trifluoromethyl analogues of vitamin D metabolites. We thank Central Glass Co., Ltd. for the gift of ethyl trifluoropyruvate. We also thank Takasago International Co. for providing $(S)$ - and $(R)$-BINAP, $(S)$-tol-BINAP, and $(S)$ SEGPHOS.

\section{References and notes}

${ }^{\S}$ Taken in part from Master theses: (a) Fujita, K. Master Thesis, Tokyo Institute Technology 2010; (b) Aida, J. Master Thesis, Tokyo Institute Technology 2010.

1. a) Tsuji, J. Organic synthesis by means of transition metal complexes, Springer-Verlag: Berlin, 1975; b) Tsuji, J. Palladium reagents and catalysts: new perspectives for the 21st century, Wiley: New York, 2004; c) Tsuji, J. Acc. Chem. Res. 1969, 2, 144; d) Tsuji, J. Acc. Chem. Res. 1973, 6, 8; e) Trost, B. M. Acc. Chem. Res. 1980, 13, 385.

2. a) Review: Moritani, I.; Fujiwara, Y. Synthesis, 1973, 524; b) Fujiwara, Y.; Moritani, I.; Danno, S.; Asano, R.; Teranishi, S. J. Am. Chem. Soc. 1969, 91, 7166; c) Fuchita, Y.; Hiraki, K.; Kamogawa, Y.; Suenaga, M.; Tohgoh, K.; Fujiwara, Y. Bull. Chem. Soc. Jpn, 1989, 62, 1081.

3. Tsuji, J.; Nagashima, H. Tetrahedron 1984, 40, 2699.

4. Mikami, K.; Hatano, M.; Terada, M. Chem. Lett. 1999, 55.

5. Hiersemann, M.; Nubbemeyer, U. Eds. The Claisen Rearrangements Wiley: New York, 2007.

6. a) Akiyama, K.; Mikami, K. Tetrahedron Lett. 2004, 45, 7217; b) Mikami, K.; Takahashi, K.; Nakai, T. Tetrahedron Lett. 1987, 28, 5879; c) Mikami, K.; Takahashi, K.; Nakai, T. J. Am. Chem. Soc. 1990, 112, 4035; d) Mikami, K.; Takahashi, K.; Nakai, T.; Uchimaru, T. J. Am. Chem. Soc. 1994, 116, 10948; e) Mikami, K.; Akiyama, K. In Ref. 4;

7. a) Hao, J.; Hatano, M.; Mikami, K. Org. Lett., 2000, 2, 4059; b) Mikami, K.; Aikawa, K.; Yusa, Y.; Hatano, M. Org. Lett., 2002, 4, 91; c) Mikami, K.; Aikawa, K.; Yusa, Y. Org. Lett., 2002, 4, 95; d) Aikawa, K.; Kainuma, S.; Hatano, M.; Mikami, K. Tetrahedron Lett., 2004, 45, 183 : Herein, the concept of trifluoropyruvate-ene approach to the side chain syntheses of vitamin D analogues including carcitriol lactone had been already shown; e) Mikami, K.; Aikawa, K.; Kainuma, S.; Kawakami,. Y.; Saito, T.; Sayo, N.; Kumobayashi H. Tetrahedron: Asymm. 2004, 15, 3885 .

8. a) Hao, J.; Taktak, S.; Aikawa, K,; Yusa, Y.; Hatano, M.; Mikami, K. Synlett, 2001, 1443; b) Ref. 7e; c) Aikawa, K.; Asai, Y.; Hioki, Y.; Mikami, K. Tetrahedron: Asymmetry 2014, 25, 1104.

9. a) Mellor, D. P.; Maley, L. Nature, 1947, 159, 370; b) Nature, 1948, 161, 436.

10. Reviews: a) Kirsch, P. Modern Fluoroorganic Chemistry: Synthesis, Reactivity, Applications (2nd, completely revised and enlarged ed.); Wiley-VCH: Weinheim, 2013; b) Mikami, K.; Itoh, Y.; Yamanaka, M. Chem. Rev. 2004, 104, 1; c) Ma, J.-A.; Cahard, D. J. Fluorine Chem. 2007, 128, 975; d) Shibata, N.; Mizuta, S.; Kawai, H. Tetrahedron: Asymmetry 2008, 19, 2633; e) Ma, J.-A.; Cahard, D. Chem. Rev. 2008, 108, PR1; f) Nie, J.; Guo, H.-C.; Cahard, D.; Ma, J.-A. Chem. Rev. 2011, 111, 455; g) Xu, X.-H.; Matsuzaki, K.; Shibata, N. Chem. Rev. 2015, 115,731 .

11. Reviews: a) Ojima, I. Ed. Fluorine in Medicinal Chemistry and Chemical Biology; Wiley-Blackwell: Chichester, 2009; b) Bégué, J.-P.; B- Delpon, D. Eds. Bioorganic and Medicinal Chemistry of Fluorine Wiley: Chichester, 2008; c) Muller, K.; Faeh, C.; Diederich, F. Science 2007, $317,1881$.

12. a) Betageri, R.; Zhang, Y.; Zindell, R. M.; Kuzmich, D.; Kirrane, T. M.; Bentzien, J.; Cardozo, M.; Capolino, A. J.; Fadra, T. N.; Nelson, R. M.; Paw, Z.; Shih, D.-T.; Shih, C.-K.; Zuvela-Jelaska, L.; Nabozny, G.; Thomson, D. S. Bioorg. Med. Chem. Lett. 2005, 15, 4761; b) Lee, T. W.; Proudfoot, J. R.; Thomson, D. S. Bioorg. Med. Chem. Lett. 2006, 16, 654; c) Song, J. J.; Tan, Z.; Xu, J.; Reeves, J. T.; Yee, N. K.; Ramdas, R.; Gallou, F.; Kuzmich, K.; DeLattre, L.; Lee, H.; Feng, X.; Senanayake, C. H. J. Org. Chem. 2007, 72, 292. d) Fandrick, D. R.; Reeves, J. T.; Bakonyi, J. M; Nyalapatla, P. R.; Tan, Z.; Niemeier, O.; Akalay, D.; Fandrick, K. R.; Wohlleben, W.; Ollenberger, S.; Song, J. J.; Sun, X.; Qu, B.; Haddad, N.; Sanyal, S.; Shen, S.; Ma, S.; Byrne, D.; Chitroda,
A.; Fuchs, V.; Narayanan, B. A.; Grinberg, N.; Lee, H.; Yee, N.; Brenner, M.; Senanayake, S. H. J. Org. Chem. 2013, 78, 3592.

13. a) Wettstein, A. Chemistry of fluorosteroids and their hormonal properties, in carbon-fluorine compounds; chemistry, biochemistry and biological activities, Elliott, K.; Birch, K. Eds. Wiley: Chichester, UK 1972; Tetrahedron reports: b) Chapelon, A.-S.; Moraleda, D.; Rodriguez, R.; Ollivier, C.; Santelli, M. Tetrahedron, 2007, 63, 11511; c) Saraber, F. C. E.; de Groot, A. Tetrahedron, 2006, 62, 5363; d) Jankowski, P.; Marezak, S.; Wicha, J. Tetrahedron, 1998, 54, 12071.

14. Feldman, D.; Glorieux, F. H.; Pike, L. W. Eds. Vitamin D, Academic Press: San Diego, 1997.

15. Dainippon-Sumitomo/Taisho Pharmaceutical Co. Ltd.

16. a) Miura, D.; Manabe, K.; Gao, Q.; Norman, A. W.; Ishizuka, S. Febs Lett. 1999, 460, 297; b) Takenouchi, K.; Sogawa, R.; Manabe, K.; Saito, H.; Gao, Q.; Miura, D.; Ishizuka, S. J. Steroid Biochem. Mol. Biol. 2004, 89-90, 31-34.

17. a) Trost, B. M.; Jiang, C. Synthesis 2006, 369; b) Hawner, C.; Alexakis, A. Chem. Commun. 2010, 46, 7295; c) Quasdorf, K. W.; Overman, L. E. Nature 2014, 516, 181.

18. a) Trost, B. M. Science, 1991, 254, 1471; b) Trost, B. M. Angew. Chem. Int. Ed. Engl. 1995, 34, 259.

19. K. Mikami, K. Aikawa, A. Ishii, K. Mogi, T. Ootsuka, WO2008078601, 2008.

20. a) Jørgensen, K. A.; Johannsen, M.; Yao, S.; Audrain, H. Thorhauge, J. Acc. Chem. Res., 1999, 32, 605; b) Johnson, J. S.; Evans, D. A. Acc. Chem. Res., 2000, 33, 325.

21. Yamamoto, K.; Shimizu, M.; Yamada, S. J. Org. Chem. 1992, 57, 33.

22. Trost, B. M; Dumas, J.; Villa, M. J. Am. Chem. Soc. 1992, 114, 9836.

23. When compounds $(25 S)-14$ ' and $(25 R)-14$ ' were tested, the $\mathrm{EC}_{50}$ value of $1,25-(\mathrm{OH})_{2} \mathrm{D}_{3}$ was $0.638 \mathrm{nM}$, while compound $(23 S, 25 S)-12$ was tested, the $\mathrm{EC}_{50}$ value of $1,25-(\mathrm{OH})_{2} \mathrm{D}_{3}$ was $0.836 \mathrm{nM}$.

24. Aikawa, K.; Miyazaki, Y.; Mikami, K. Bull. Chem. Soc. J. 2012, 85, 201. 